\title{
CORONA AND THE COMMONS
}

\author{
Michel Bauwens ${ }^{1}$ \\ P2P Foundation \\ michel@p2pfoundation.net
}

\begin{abstract}
The article addresses an important stage that the pandemic brought to the transition of the transition from the "old" to the "new" ways of organising Society. Points to an attitude emerging from changes. The Corona crisis, despite weaknesses and errors, has shown what can be done and how quickly institutions can adapt and change their choices, since life is at stake and, therefore, its legitimacy. This process towards 'partner state' practices and public-commons protocols will not be automatic, and will be an alternative to a coercive and authoritarian state-centric model, which could be one of the negative outcomes of this crisis.
\end{abstract}

Keywords: Coronavirus. Commons Transition. Public-Commons.

\section{O CORONAVÍRUS E O COMUM}

\section{Resumo}

O artigo aborda um importante estágio que a pandemia trouxe para a transição das "velhas" às "novas" formas de organização da sociedade. Aponta para uma atitude emergente de mudanças de lutar por adaptações e reformas estruturais, bem como propor reformas centradas em bens comuns e políticas transformadoras a mobilização global. A crise Corona, apesar das fraquezas e erros, tem mostrado o que pode ser feito e com que rapidez as instituições podem se adaptar e mudar suas escolhas, uma vez que está em jogo a vida e, portanto, sua legitimidade.

Palavras-chave: Coronavirus. Transição Commons. Commons Publico.

\footnotetext{
${ }^{1}$ Bibliotecário. Diretor e fundador da Fundação P2P. Ativista e pesquisador do Peer-to-Peer e do Commons.
} 


\section{ARTIGO}

INOVAÇÃo

\section{INTRODUCTION}

Dear all, I had been reviewing, before the Corona outbreak, and with the help of Jose Ramos, the lead editor of a upcoming book about cosmo-local production, the literature on historical rythms and cycles, to set the stage for the current 'chaotic transition' and 'what comes next'.

In short, I have come to two important conclusions:

1) society moves from relative stable stages, through chaotic transitions, which are real mutations both in human consciousness and in socio-economic structures

2) this change is non-linear and moves through internal or external shocks.

Clearly, Corona is such a shock, partly exo-genous, i.e. a unpredictable outside factor, but also partly endo-genous (internal factor), since our devastating ecological practices are an important part of pandemic generation. It's a double whammy which both endangers human life and creates a double shock to the economic system (both demand and supply driven, this is quite unprecedented, as economic crisis usually alternate between one and the other). Corona is not going to be sufficient for a full transition, but it will be a Great Accelerator, which has already changed so much in such a short time. I am not predicting that the results will be uniformly positive (accelerating the green/p2p/commons transition), or negative (KLEIN, 2008). Think about what happened after the fall of Rome, to see a mixture of radical changes.

\section{NEVERTHELESS SOME PRELIMINARY CONCLUSIONS}

1) the market plays almost no role in finding solutions in such crisis moments and $90 \%$ of big and small companies would go bankrupt without state support (right now, big banks are pressing big pharma to price-gouge even more the vital medicines in the US!!). Of course, this is not to belittle the many SME's which are rooted in their communities and doing their best to somehow contribute to these communities, but the proper 'capitalist' multinational and financial entities would have created a situation in which the poor would have been condemned to die for lack of affordable testing and medicines thereby endangering the population as a whole. Here is a short list of market failures that have aggravated the crisis:

- neoliberal austerity measures have devasted public health infrastructures, and private hospital using patented medicines are unaffordable to the mass of people); 
- global just-in-time supply chains, most starting off in China, have grown to a halt, showing a total lack of resilience in other countries, who have strategic reserves of medical devices, testing kits, etc.

2) the nation-states are weak and the leaders have made mistakes, but it turns out to be to be an absolutately indispensible institution to avoid chaotic reactions from a fragmented social field, AND to discipline the market so that everyone is not put in even graver danger. Neverthess, the current 'market state' form has been pursuing an agenda that fundamentally weakened our response; the hesitation of political leaders to follow the example of the succesful suppression policies in East Asia have increased the death toll substantially. It is still not reacting adequately to the failures of the private sector in providing us with medical solutions.

3) the current multilateral regime has been useful, (WHO, 2020), but also rather weak and ineffectual, at least insufficient to the task; many people have died because of the weakness of factor 2 and 3, but paradoxically, an enormous larger amount would have died without them; all in all, they are playing a vital role and after initial delays and mistakes, most of them adapted to relatively sensible policies. We should not entertain any illusions that the abolishing of state forms would be anything else than a grave disaster in this context.

4) we have seen an extraordinary civic spirit and collaborative mobilisation of civil society which has been vital in the adaptation to the crisis, and to mitigate market and state failures; countless local and trans-local groups have been set in motion to create technical and scientific commons capable to rapidly produce medical devices that the market had not in stock and the state failed to order in time. Without valves and ventilators, the sick die; without masks, medical personnel gets infected and citizens continue to infect each other at too rapid rates; without mass testing we cannot move from mitigation to suppression; in all these efforts, civil society groups have taken the lead. Neverteless, it has also been a largely chaotic process, not well coordinated with the medical sector and experts, unsupported by the state and public funding. It's a shadow of what it can be with adequate support and publiccommons protocols to smoothen collaboration.

5) what has been emerging through $\mathrm{p} 2 \mathrm{p} / \mathrm{commons} / \mathrm{open}$ source efforts are the seeds of new institutions for trans-local, trans-national responses, which can at this stage, not replace, but greatly strenghthen the nation-station/multilateral regime, insufficient to the task as may be. (we will need a much stronger trans-national, not inter-natioal, multilateral institutions in the future, which can guarantee that the human economy works within planetary boundaries 
and acceptable social equity parameters, as ecological and social justice are strongly dependent on each other)

This regime, which is now still dominant and necessary, can order around market players, as they are now doing through new legislation that both saves and coerces/mobilizes market players; but most of all, it needs to work with, and help mobilize, the collective intelligence of trans-local and trans-national expertise which is strongly needs to be more effective itself. This proces towards 'partner state' practices and public-commons protocols will not be automatic, and will be an alternative to a coercive and authoritarian state-centric model, which could be one of the negative outcomes of this crisis.

\section{SO WHAT IS THE ROLE OF THE COMMONS MOVEMENT?}

1) One is to show and demonstrate what we can do, as we have already done through the multitude of open source efforts to market and state failures as well as mutual aid selforganizing.

2) Use the opportunity of this pedagogical catastrophe to strive for structural adaptations and reforms. In other words, we can't just be local and tribal, we must be translocal, work at every level of institutional life, to transform institutions and proposes commons-centric reforms and transformative policies. The Coronavirus crisis is also a nonlinear opportunity for longer-term agenda setting to promote the necessary deep reforms and transformations that need to take place so humanity can take care of its needs within the planetary boundaries and in recognition of its interdependency with other life forms.

Corona is a serious crisis, but the climate is a much more serious one. In a paradoxical way, the global mobilization against Corona, despite the weakness and mistakes, has shown what can be done, and how fast institutions can adapt and change their choices, once our life and thus, their legitimacy, is at stake. This bodes well for climate change adaption and ecological transformation. But make no mistake, this is just one of the crises we will need. The deep transformation that we need for this bifurcation, requires a 'mutation of consciousness', on a par with the ones we had in the 11th and 16th cy in Europe, though this time, it will need to be global and fairly 'simultaneous'.

\section{CONCLUSION}

We are not there yet, but we're definitely seeing strong premises for it, and for which this crisis acted as a revealer. This is just the first of the pedagogical catastrophes that will 


\section{ARTIGO}

: INOVAÇÃo

force the necessary transformations to a new stable system, that lives within the confines of nature, and realizes its interdependence with all other life forms; It will need to escape the historical cycle of pulsation between extractive regimes leading to ecological crisis, and the regenerative responses that human societies have always brought; Instead, we will need to move to a steady-state economic and social regime, that can last many centuries and millenias. 


\section{ARTIGO}

: INOVAÇÃo

\section{REFERENCE}

COMMONS Transition and P2P: transnational institute a primer. Available from: https://www.tni.org/files/publicationdownloads/commons_transition_and_p2p_primer_v9.pdf. Access in: 12 apr. 2020.

KLEIN, Naomi. The Shock Doctrine: The Rise of Disaster Capitalism. New York: Picador, 2008 .

WORLD HEALTH ORGANIZATION. "Solidarity" clinical trial for Covid-19 treatments. Geneve: WHO, jun. 4, 2020. 